\title{
降雨時における集団茶園流域の河川水質と流出負荷特性
}

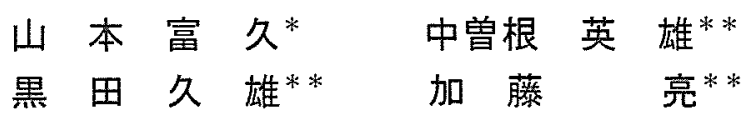

\section{Characteristics of River Water Quality and Storm Runoff Load from Collective Tea Field Catchment}

\author{
Tomihisa YAMAMOTO*, Hideo NAKASONE**, \\ Hisao KURODA** and Tasuku KATOU**
}

\footnotetext{
* Department of Agricultural Science, Shuchi High School, Mori 92-1, Shuchi, Shizuoka 437-0215, Japan

** Department of Regional Enviromental Science, School of Agriculture, Ibaraki University, Ami-Chuoh 3-21-1, Inasiki 300-0393, Japan
}

\section{Abstract}

In this study, we discuss the storm runoff load for a collective tea field catchment. The study area was Makinohara plateau, in Shizuoka, Japan. The water quality and discharge were measured during a storm period. Heavy rain occurred due to a Bai-u front or cyclone during the rainy and typhoon seasons from June to September. Compared with clear weather days, $\mathrm{NO}_{3}-\mathrm{N}$ concentration during heavy rain decreased to $1 / 3$. However the T-P and $\mathrm{COD}$ concentrations increased $2 \sim 23$ times. The average recovery rate of $\mathrm{NO}_{3}-\mathrm{N}$ concentration was $3 \mathrm{mg} \cdot l^{-1} \cdot \mathrm{d}^{-1}$. Hysteresis was observed in the relation between the discharge and the loads. The loads $\mathrm{NO}_{3}-\mathrm{N}$ becomes higher when discharge was decreased than when it was increased. On the other hand, the load of T-P showed a reverse tendency, and the load of COD was similar, too. The loads in periods of storm runoff are heavily affected by the amount of rainfall and antecedent conditions.

Key words : collective tea field, storm runoff load, rainy and typhoon seasons, heavy rain, hysteresis

\section{1. はじめに}

茶樹は永年性の需葉作物であるため ${ }^{1,2)}$, 古くから肥料 の中でも，特に窒素肥料の重要性が認識されていた ${ }^{3,4)}$ 。 このことから，高品質茶の高生産のため，茶園における 年間施肥窒素量は，一時期 $1,000 \mathrm{~kg} \cdot \mathrm{ha}^{-1} \cdot \mathrm{y}^{-1}$ を大幅に超え ていた

こうした茶園での過剩な施肥は，周辺の河川や地下水 など，公共用水域における硝酸態空素による水質污染の 原因であることが指摘された 6)。このことから，茶栽培 の指導機関は，茶栽培に扮ける施肥基準の遵守，適正施 肥，施肥管理の改善を推進している7)。

この現状の中で，降雨時における茶園流域からの流出 負荷を正確に把握することは重要なことである。そのた めには，晴天時の観測データから求めた流出負何のみで はなく，大雨や強雨などの降雨時を含めた観測結果を基 に算出した流出負荷の検討が必要である。

降雨時における流出負何に関する先駆的な研究として， 中曾根 ${ }^{8)}$ らが行った調查事例がある。その後，降雨時に
おける流出負荷の重要性が認識され，これに関した研究 が活発に行われるようになった。これらの研究には，一 般河川 ${ }^{9,10)}$ ，農業地域の小河川 ${ }^{11)}$ ，水田地域 ${ }^{12)}$ ，森林流 域 ${ }^{13)}$, 養豚地域 ${ }^{14)}$ や海外における事例 ${ }^{15,16) な と ゙ か ゙ あ る か ゙ ， ~}$ 研究数は少ない。さらに既往の研究は，窒素濃度が最大 $5 \mathrm{mg} \cdot l^{-1}$ 程度で, 総降雨量が $10 \sim 100 \mathrm{~mm}$ 程度の流出を対 象としたものである。高排出負荷地域である茶園流域に おける降雨時の流出負荷を対象としたものや，一連の断 続した総降雨量が $300 \mathrm{~mm}$ ，日降雨量が $100 \mathrm{~mm} \cdot \mathrm{d}^{-1}$ ，時間 降雨強度が $30 \mathrm{~mm} \cdot \mathrm{h}^{-1}$ を超える記録的な降雨を対象とし た研究は，今後の課題の一つである。

こうした梅雨期の長雨や台風時の大雨, 強雨, 索雨は, 洪水を引き起こすことが多く ${ }^{17)}$ ，観測には非常に大きな 危険を伴うことが考えられる。しかし，こうしたときの 窒素やリンなどの流出負荷は,「洪水時の負荷は相当大き く，それは無視できないばかりか，むしろ主役である」 ともいわれている11。

また，梅雨期の長雨や台風による一連の断続的な強雨 に見舞われた時, 流域の土䗙中には，先行降雨が滞留し

\footnotetext{
* 静岡息立周智高等学校生產科学科 $\overline{\mathrm{T}} 437-0215$ 周智郡森町森 92-1

(現在静岡県立天竜林業高等学校環壋システム科 $\bar{T} 431-3314$ 浜松市二俣町二俣 601)

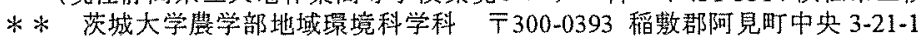


ているため ${ }^{18)}$, 一降雨時の流出負荷とは大幅に異なるこ とが考えられる。

さらに茶の栽培が行われている平坦な台地流域からの 流出負荷は, 特異的な土壌, 地形・地質学的条件, その 時季の降雨の水文学的性質, 独特な茶専作の栽培環境に も大きく影篦されると考えられる。

本研究は，茶の溨培が盛んで，国内最大の集団茶園地 帯を形成する静阙県牧/原台地を調查地とし, 降雨時, 中でも，特に梅雨期の長雨や台風時の強雨の流出時にお ける河川水質と流出負荷の特性について検討を行った。

\section{2. 調 查 地 域}

調查河川は，静岡県牧ノ原台地北西地域を集水域とす る丹野川である。その流域の概要を Fig.1 に示す。土地 利用は，茶園が $65.3 \mathrm{ha}(58.6 \%)$, 林地が $44.5 \mathrm{ha}(40.0 \%)$, 道 路や宅地は 1.6ha(1.4\%)である。台地上はほとんどが茶園 として利用され，茶単作地带を形成し，段丘崖は山林で ある。台地における降雨は，Fig.2に示す水理地質学的断 面加分かるように，表層土，牧ノ原㗜層を浸透し，不 透水の第三紀層泥岩上加ら湧出し ${ }^{19)}$, 丹野川の河川水に 流出する。

\section{3. 茶の栽培環境}

台地の表層土は赤黄色士壤で，強酸性土䘫である ${ }^{20)}$ 。 その下層土は，緻密で透水性が悪い21)。

静阙県における茶園の施肥基準は，普通園で目標の摘 採量を Iha 当たり $18,000 \mathrm{~kg} \cdot \mathrm{ha}^{-1} \cdot \mathrm{y}^{-1}$ としたとき，肥料成 分で，窒素が $540 \mathrm{~kg} \cdot \mathrm{ha}^{-1} \cdot \mathrm{y}^{-1}$ ，リンが $180 \mathrm{~kg} \cdot \mathrm{ha}^{-1} \cdot \mathrm{y}^{-1}$ ，力 リウムが $270 \mathrm{~kg} \cdot \mathrm{ha}^{-1} \cdot \mathrm{y}^{-1}$ である ${ }^{22)}$ 。茶園の施肥量と，そ の時期を Table 1 に示す。茶園での窒素施肥は，1回の上 限の施肥量が 1 ha 当たり $100 \mathrm{~kg} \cdot \mathrm{ha}^{-1}$ 程度とし, 施肥間隔 を20日以上とするため, 実際には年間 7 回前後に分施さ れていた。

近年, 茶園での施肥量は「茶の栽培履歴」への記録, 提出が義務化されたため，施肥基準唒遵守されていると 考えられる。肥料のほとんどが複合肥料で，一部緩効性 肥料も使用され，その他堆肥や菜種油粕，大豆油粕など の有機質肥料も施していた。茶園は施肥時に中耕し，秋 冬季に野草などの粗大有機物で被覆されていた。

\section{4. 調疽方法}

\section{1 水文調查}

調查は, 2000 年がら 2003 年までのうち, 大雨, 強雨 に見舞われた期間に行った。

降雨量は，約 $4 \mathrm{~km}$ 北方に位置する牧／原地域気象観測 所が観測したデータを用いた ${ }^{23)}$ 。調查対象は，一連の断 続した降雨のうち，総降雨量が 289〜550mm，日降雨量 が 141 228mm・d $\mathrm{d}^{-1}$ ，または時間降雨強度が $24 \sim 75 \mathrm{~mm} \cdot \mathrm{h}^{-1}$ の降雨である。

水位测定と採水定点を Fig.1 に示卞。水位観測は，丹
野川の採水定点に水位計を設置し，調査期間中 1 時間間 隔で測定した。流量観測は，試水回収時に行い，H-Q曲 線を作成した。それを用いて，水位計のデータから流量 を算出した。これを比流量に換算し，水質濃度を借じて 比負荷を求めた。

\section{2 採水および水質分析}

水質調查におりる採水頻度は，水質や流出負荷の測定

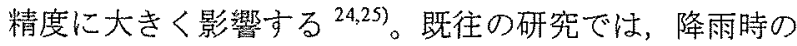
採水頻度は，数十分から十数時間の間隔であるが8,11-14)， 本調査では 24 時間間隔の頻度で採水を行った。

これは，次のような理由からである。すなわち，調査 地は，Fig.2に示すように，全域が通年，茶樹で覆われた 茶園地帯で，緩やかな起伏をもつ台地流域であること， 表土の下層土は排水不良で降雨が滞留しやすいこと，さ らに，その下層の碩層間には複数の難透水の粘土層が存

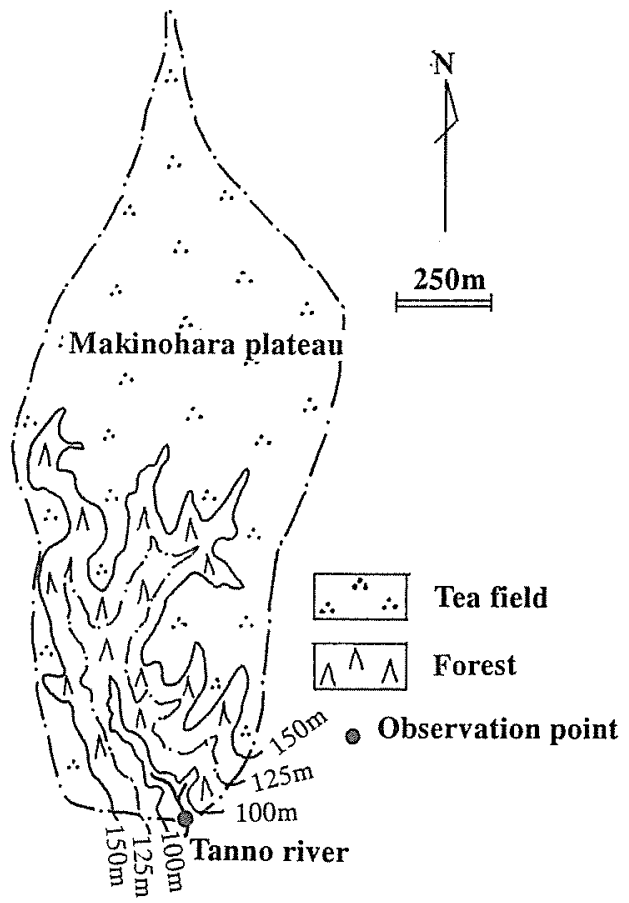

Fig.1 Study area

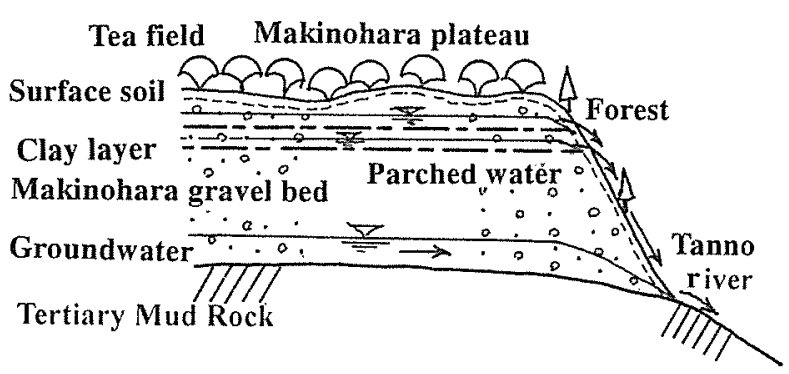

Fig.2 Hydrogeologic section

Table 1 Fertilizer

\begin{tabular}{|c|c|c|c|c|}
\hline Season & $\mathrm{N}$ & $\mathrm{P}_{2} \mathrm{O}_{5}$ & $\mathrm{~K}_{2} \mathrm{O}$ & Monthly of ten days \\
\hline Spring & 100.0 & 90.0 & 130.0 & Late in Feb. early in Mar. \\
\hline Budding & 60.0 & - & - & Late in Mar. $\sim$ early in Apr. \\
\hline Summer I & 110.0 & - & - & In mid-May \\
\hline Summer II & 110.0 & - & - & Early in Jul. \\
\hline Autumn & 160.0 & 90.0 & 140.0 & Early in Sept. \\
\hline Total & 540.0 & 180.0 & 270.0 & \\
\hline
\end{tabular}


在し，対象とした総降雨量が大きく，地層中に宙水在形 成，保持，貯留されること ${ }^{26)}$ ，また，河川水性，台地を 棈成する磂層底部の地下水流動により供給されることな ビがその理由である。

これらの水文気象学的条件加ら文て，台地流域が多量 の降雨に見舞われると，降雨は浸透後，地層内に滞留す る。このため，そこからの流出形態は，長期にわたり非

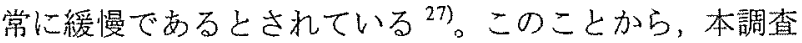
での採水頻度は，本流域の流出に対し水質データの捕捉 が可能である。また，この測定間隔は，降雨後の流出水 量の低減に伴う水質変動を追跡しやすいことも考えられ る。以上のことから採水定点に自動採水器を設置し， 1 日 1 回，午前 6 時に定時採水を行った。

水質分析用の試水は，1 週間毎に回収し，試験室に保 冷しながら輸送し，分析に供した。硝酸態窰素 $\left(\mathrm{NO}_{3}-\mathrm{N}\right)$ はイオンクロマトグラフ法, 全リン(T-P)は環境省告示法, COD は過マンガン酸カリウム法により測定した。

\section{5. 調查結果および考察}

\section{1 降雨の水文学的性筫}

Table 2 に2000年から 2003 年における年間降雨量とそ の平年值，6月から9月までの多雨期（以下，多雨期上 いう）における降雨量を示す。多雨期の総降雨量は，年 間降雨量の $50.3 \%$ 占め, 特に梅雨期の降雨量と台風が もたらす降雨量が非常に多く，重要な水資源となってい る $^{28)}$ 。

調查対象とした降雨の水文学的性質を Table 3 に示卞。 これらは，総降雨量が 200〜300mm を超える大雨，また は時間降雨量が 30 50 mm・h -1 $^{-1}$ 超える強雨である ${ }^{18)}$ 。 それらには，豪雨を伴うことが多く，す心゙て多雨期に生 起したものである。この降雨は，梅雨期の前線，台風， 低気圧や雷雨に伴って発生する ${ }^{29,30)}$ 。

牧ノ原地域における年間降雨量の平年值は, $2,141 \mathrm{~mm}$. $\mathrm{y}^{-1}$ でありこれらの一連の断続した総降雨量は 13.5 $25.7 \%$ に達する。最大日降雨量は 2002 年 7 月 10 日の $228 \mathrm{~mm} \cdot \mathrm{d}^{-1}$ （1979 年の観測開始以降，史上（以下，史上 という） 4 位，時間降雨強度 $51 \mathrm{~mm} \cdot \mathrm{h}^{-1}$ ), 最大時間降雨強 度は, 2001 年の 8 月 21 日の $75 \mathrm{~mm} \cdot \mathrm{h}^{-1}$ (日降雨量 $173 \mathrm{~mm}$. $\left.\mathrm{d}^{-1}\right)$ であった。
過去 30 年間の観测結果では，台風の年間接近数，年間

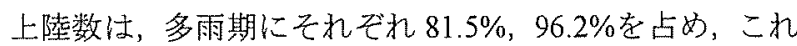
による降雨が非常に多い。近年，年間降雨量(2003 年, $2,568 \mathrm{~mm} \cdot \mathrm{y}^{-1}$, 史上 4 位), 月間降雨量(2003 年 8 月, $593 \mathrm{~mm} \cdot$ month $^{-1}$ ，史上 4 位)，日降雨量(2002 年，228 mm $\mathrm{d}^{-1}$ ，史 上 4 位)，時間降雨強度 $\left(2001\right.$ 年, $75 \mathrm{~mm} \cdot \mathrm{h}^{-1}$ ，史上 6 位 $)$ に，記録的な值がみられる。

\section{2 降雨時の水質の経時変動}

降雨流出時における $\mathrm{NO}_{3}-\mathrm{N}, \mathrm{T}-\mathrm{P}, \mathrm{COD}$ 蕽度の单純平 均柱，それぞれ $20.1 \mathrm{mg} \cdot l^{-1}, 0.020 \mathrm{mg} \cdot l^{-1}, 2.3 \mathrm{mg} \cdot l^{-1}$ であ った。No.1 No.5の降雨時の $\mathrm{NO}_{3}-\mathrm{N}, \mathrm{T}-\mathrm{P}, \mathrm{COD}$ 濃度の 経時变動索 Fig.3〜6に示す。ま，その降雨前濃度とピ 一ク濃度の関係を Table 4 に示す。

No.1 No.5の降雨時での観湘をとおして，Fig.3〜6に 示す $\mathrm{NO}_{3}-\mathrm{N}$ 濃度と日降雨量, 比流量との関係は, 弱い逆 相関（各々 $\mathrm{r}=-0.41, r=-0.43$, 各々 $\mathrm{n}=100, \mathrm{P}<0.0001)$ が あり，有意であった。

各降雨時における降雨前の $\mathrm{NO}_{3}-\mathrm{N}$ 檂度は $20 \sim 30 \mathrm{mg} \cdot l^{-1}$ であるが，最低濃度は 8 10 $\mathrm{mg} \cdot l^{-1}$ と，約 $1 / 3$ の淟度に一 挙に低下した。既往の研究では，降雨流出時の $\mathrm{NO}_{3}-\mathrm{N}$ 浱

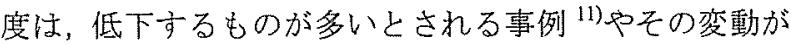

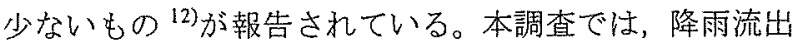
時の $\mathrm{NO}_{3}-\mathrm{N}$ 濃度は, す心゙て低下した。

こうした差異は, 調査地の地形・地質学的条件, 土地 利用，作物の栽培環境，排出負荷量，さらに対象とした 降雨の水文学的性質などの影響によるものと考えられる。 本調查地に打ける降雨流出時の $\mathrm{NO}_{3}-\mathrm{N}$ は, 茶園土壤中 の残留害素が多量の降雨によって溶脱・希釈され，表面 流出水执よび下層一浸透したものが，䃯層底部から流出 し，河川水に供給されたと考えられる。

Table 5 に降雨後の $\mathrm{NO}_{3}-\mathrm{N}$ 濃度の最小值と最大值を示

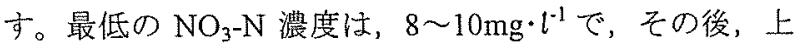
限の $24 \sim 27 \mathrm{mg} \cdot l^{-1}$ に回復した。このとき, 降雨後 $1 \sim$

Table 2 Annual Precipitation

\begin{tabular}{l|llll}
\hline Year & 2000 & 2001 & 2003 & Normal \\
\hline Precpitation & 1,987 & 1,997 & 2,564 & 2,141 \\
Jun. Sept. & 1,059 & 1,051 & 1,284 & 1,042 \\
\hline Unit : $\mathrm{mm} \cdot \mathrm{y}^{-1}$ & & & &
\end{tabular}

\begin{tabular}{|c|c|c|c|c|c|c|c|c|}
\hline $\begin{array}{l}\text { Rainfall } \\
\text { No. }\end{array}$ & $\begin{array}{c}\text { Storm runoff } \\
\text { Period } \\
(y / m / d)\end{array}$ & $\begin{array}{l}\text { Amount of } \\
\text { rainfall } \\
(\mathrm{mm})\end{array}$ & $\begin{array}{l}\text { Maximum } \\
\text { Rainfall } \\
\text { intensity } \\
\left(\mathrm{mm} \cdot \mathrm{d}^{+1}\right)\end{array}$ & $\begin{array}{l}\text { Maximum } \\
\text { Rainfall } \\
\text { intensity } \\
\left(\mathrm{mm} \cdot \mathrm{h}^{-1}\right)\end{array}$ & $\begin{array}{l}\text { Preceding } \\
\text { Fine days } \\
\text { (day) }\end{array}$ & $\begin{array}{l}\text { Preceding } \\
\text { Monthly } \\
\text { rainfall } \\
\left(\mathrm{mm} \cdot \mathrm{m}^{-1}\right)\end{array}$ & $\begin{array}{l}\text { Preceding } \\
\text { Monthly } \\
\text { rain day } \\
\text { (day) }\end{array}$ & Factor \\
\hline $\begin{array}{l}\text { No.1 } \\
\text { No.2 } \\
\text { No.3 } \\
\text { No.4 } \\
\text { No.5 }\end{array}$ & $\begin{array}{l}2000 / 6 / 8 \sim 2000 / 6 / 29 \\
2001 / 8 / 21 \sim 2001 / 8 / 22 \\
2001 / 9 / 1 \sim 2001 / 9 / 11 \\
2002 / 7 / 6 \sim 2002 / 7 / 19 \\
2003 / 8 / 8 \sim 20003 / 8 / 22\end{array}$ & $\begin{array}{l}447 \\
289 \\
366 \\
333 \\
550 *^{3} \\
\end{array}$ & $\begin{array}{l}141 \\
173 \\
209 \\
228 *^{2} \\
147 \\
\end{array}$ & $\begin{array}{l}24 \\
75 * 1 \\
31 \\
51 \\
32 \\
\end{array}$ & $\begin{array}{l}6 \\
8 \\
8 \\
4 \\
5 \\
\end{array}$ & $\begin{array}{r}140 \\
99 \\
380 \\
292 \\
239 \\
\end{array}$ & $\begin{array}{r}8 \\
7 \\
8 \\
14 \\
17 \\
\end{array}$ & $\begin{array}{l}\text { Rainy season } \\
\text { Typhoon } \\
\text { Typhoon } \\
\text { Typhoon } \\
\text { Typhoon } \\
\end{array}$ \\
\hline
\end{tabular}

*: Observational record rank $6, *^{2}$ : Observational record rank 4 ,

$*^{3}: 2003 /$ Aug. $593 \mathrm{~mm}^{*}$ month $^{-1}$, Observational record rank 4

Table 4 Minimum, Maximum concentrations of $\mathrm{NO}_{3}-\mathrm{N}, \mathrm{T}-\mathrm{P}$ and $\mathrm{COD}$ in each runoff

\begin{tabular}{|c|c|c|c|c|c|c|c|c|c|}
\hline \multirow[b]{2}{*}{$\begin{array}{c}\text { Rainfall } \\
\text { No. }\end{array}$} & \multicolumn{3}{|c|}{$\mathrm{NO}_{3}-\mathrm{N}$} & \multicolumn{3}{|c|}{$\mathrm{T}-\mathrm{P}$} & \multicolumn{3}{|c|}{$\mathrm{COD}$} \\
\hline & $\begin{array}{c}\text { Before } \\
\text { rain } \\
\left(\mathrm{mg} \cdot l^{-1}\right)\end{array}$ & $\underset{\left(\mathrm{mg} \cdot l^{-1}\right)}{\operatorname{Minimum}}$ & Ratio*1 & $\begin{array}{c}\text { Before rain } \\
\left(\mathrm{mg} \cdot l^{-1}\right)\end{array}$ & $\begin{array}{r}\left.\operatorname{Maximum} \cdot 1^{-1}\right) \\
\end{array}$ & Ratio*2 & $\begin{array}{c}\text { Before } \\
\text { rain } \\
\left(\mathrm{mg} \cdot l^{1}\right)\end{array}$ & $\underset{\left(\mathrm{mg} \cdot l^{-3}\right)}{\operatorname{Maximum}}$ & Ratio* $2^{*}$ \\
\hline No.1 & 23.8 & 7.9 & 3.0 & 0.009 & 0.045 & 5.0 & 1.5 & 7.1 & 4.7 \\
\hline No. 2 & 32.2 & 9.1 & 3.5 & 0.016 & 0.044 & 2.8 & 1.1 & 15.2 & 13.8 \\
\hline No.3 & 28.3 & 9.6 & 3.0 & 0.005 & 0.044 & 8.8 & 1.5 & 4.2 & 2.8 \\
\hline No. 4 & 18.5 & 8.2 & 2.3 & 0.004 & 0.092 & 23.0 & 1.8 & 4.0 & 2.2 \\
\hline No. 5 & 27.4 & 8.1 & 3.4 & 0.011 & 0.057 & 5.2 & 0.9 & 3.5 & 3.9 \\
\hline Average & 26.0 & 8.6 & 3.0 & 0.009 & 0.056 & 6.2 & 1.4 & 6.8 & 4.9 \\
\hline
\end{tabular}

: Before rain/Minimum, ${ }^{2}:$ Maximum/Before rain 


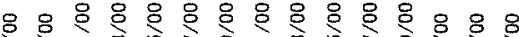
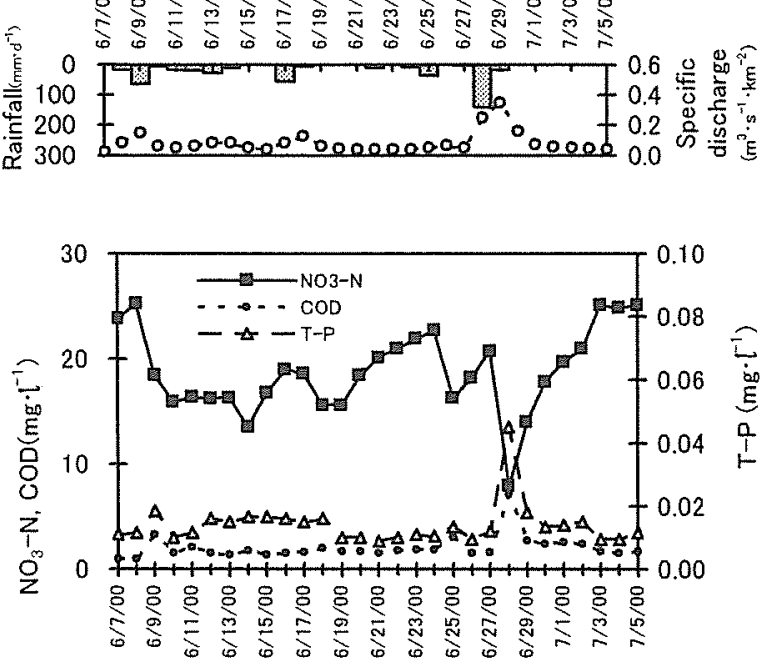

Fig. 3 Changes of discharge and concentrations in runoff No. 1

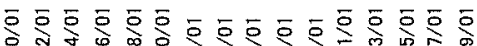

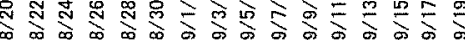
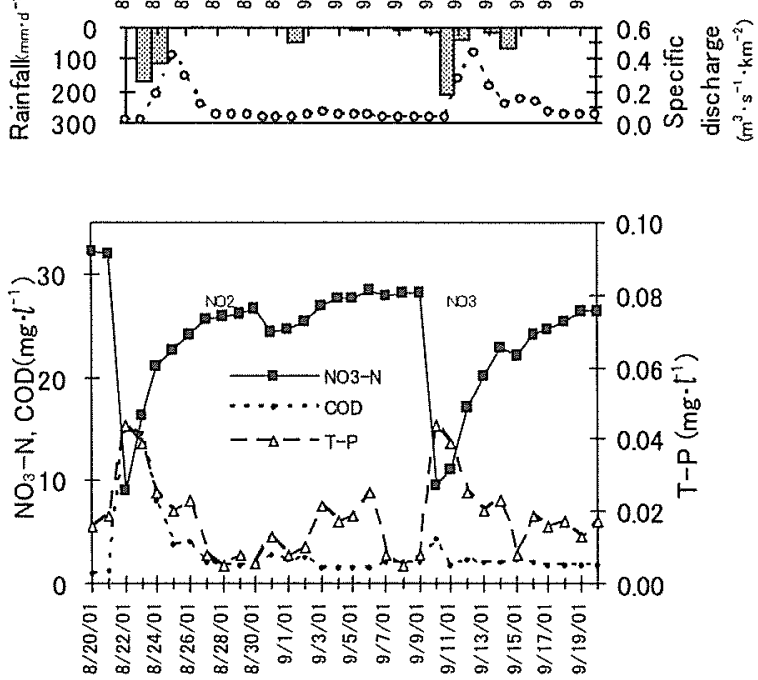

Fig.4 Changes of discharge and concentrations in runoff No.2, No.3

\begin{tabular}{c|cccc}
\hline $\begin{array}{c}\text { Rainfall } \\
\text { No. }\end{array}$ & $\begin{array}{c}\text { Minimum } \\
\left(\mathrm{mg} \cdot \mathrm{l}^{-1}\right)\end{array}$ & $\begin{array}{c}\text { Maximum } \\
\left(\mathrm{mg} \cdot \mathrm{l}^{-1}\right)\end{array}$ & $\begin{array}{c}\text { Recovery } \\
(\text { day })\end{array}$ & $\begin{array}{c}\text { Rate } \\
\left(\mathrm{mg} \cdot l^{-1} \cdot \mathrm{d}^{-1}\right)\end{array}$ \\
\hline No.1 & 7.9 & 25.1 & 5 & 3.2 \\
No.2 & 9.1 & 26.7 & 8 & 2.9 \\
No.3 & 9.6 & 26.5 & 10 & 2.8 \\
No.4 & 8.2 & 24.2 & 14 & 3.0 \\
No.5 & 8.1 & 24.8 & 8 & 3.1 \\
Average & 8.6 & 25.5 & 9 & 3.0 \\
\hline
\end{tabular}

2 日間における濃度の回復速度が大きく，その後，5～14 日かけて潮近的に回復した。降雨後， $\mathrm{NO}_{3}-\mathrm{N}$ 漕度は，放 物線状に增大した。これは降雨直後ほど，流域加らの $\mathrm{NO}_{3}-\mathrm{N}$ 溶脱量の低減よりも，流出水量の低減のほうが速 いためと考えられる。

ここでの $\mathrm{NO}_{3}-\mathrm{N}$ 濃度の回復速度は，降雨直後の最小值 と，その後の回復過程での最大值，または，ほぼ上限に 達した值との濃度差を，その間の日数で除したものとし

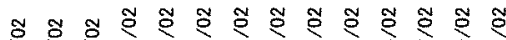
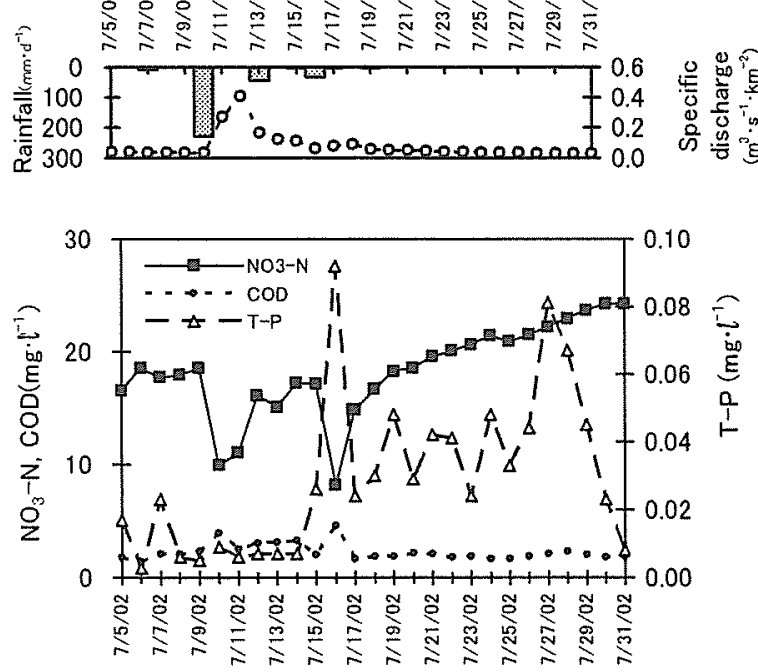

Fig.5 The changes of discharge and concentrations in runoff No.4
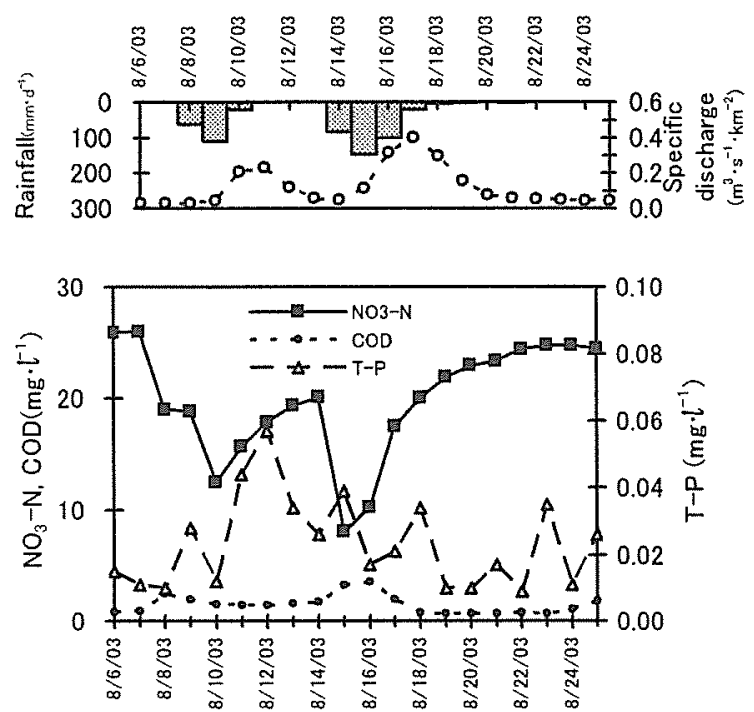

Fig.6 Changes of discharge and concentrations in runoff No.5

た。降雨 No.1 No.5 の $\mathrm{NO}_{3}-\mathrm{N}$ 濃度の回復速度は 2.8 $3.2 \mathrm{mg} \cdot l^{-1} \cdot \mathrm{d}^{-1}$, 平均 $3.0 \mathrm{mg} \cdot l^{-1} \cdot \mathrm{d}^{-1}$ であった。各降雨におけ る $\mathrm{NO}_{3}-\mathrm{N}$ 蕽度の回復速度は，降雨量の影響が少なく， 僅差であった。鈴木 ${ }^{11} ら$ ら成果から $\mathrm{NO}_{3}-\mathrm{N}$ 謴度の回復 速度を算出すると， $1 \mathrm{mg} \cdot l^{-1} \cdot \mathrm{d}^{-1}$ 以下であり，乙れが 1 日 程度でほぼ回復した。このような降雨後の $\mathrm{NO}_{3}-\mathrm{N}$ 等の水 質濃度の回復速度について，これまで報告された事例は ない。

No.1 は，ほかのケースと異なり，挴雨による長雨の影 響を大きく受けた。このケースでは，日降雨量が $100 \mathrm{~mm}$ 以下の降雨が継続したとき，低下した濃度を維持し，1 ２ 日の無降雨日に濃度が大幅に回復し，その後，日降 雨量が $100 \mathrm{~mm} \cdot \mathrm{d}^{-1}$ 孝超える降雨により，長雨により低下 した祳度よりもさらに低下した。

No.4は，21 日間のうち，15日間の断続した先行総雨 量 $292 \mathrm{~mm}$ により，既に流出濃度が $18.5 \mathrm{~m} \cdot l^{-1}$ を示し，乙 れが日降雨 $228 \mathrm{~mm} \cdot \mathrm{d}^{-1}\left(7\right.$ 月 10 日) により一挙に $9.5 \mathrm{~m} \cdot l^{-1}$ 
まで低下した。その後，比較的少雨(7月 16 日 $35 \mathrm{~mm} \cdot \mathrm{d}^{-1}$ ) に見舞われ，さらに $8.2 \mathrm{~m} \cdot l^{-1}$ まで低下した。

水質項目間では， $\mathrm{NO}_{3}-\mathrm{N}$ Ł T-P， $\mathrm{COD}$ の関倸は，とも に弱い逆相関（各 $\mathrm{r}=-0.38, \mathrm{n}=100, \mathrm{P}<0.0001$ ) を示し た。一方, T-P と COD の関係は, 弱い相関 $(\mathrm{r}=0.31, \mathrm{n}=100$, $\mathrm{P}<0.0001)$ があった。このことから，前述のように $\mathrm{NO}_{3}-\mathrm{N}$ は, 降雨流出時は濃度が低下するのに対して, 逆に T-P, COD は降雨流出に伴い降雨前の濃度よりもピーク祡度 のほうが高く示された。このT-P，CODの両者には，降 雨流出時に拈ける流出機棈等に類似性があると考えられ る。T-P, COD の中で, No.2 の COD 降雨前後の濃度 (降雨後/降雨前) 比怯, 13.8 と最も大きくなった。この とき, 総降雨量は $289 \mathrm{~mm}$ で，さらに時間降雨強度は $75 \mathrm{~mm} \cdot \mathrm{h}^{-1}$ と最大であった。こうした大雨，かう強雨によ って生起する掃流や移流により，流域内の有機物が流出 したと考えられる。

No.4 は, 2002 年 7 月 10 日に日降雨量 $228 \mathrm{~mm} \cdot \mathrm{d}^{-1}$ を生 起し，史上 4 位の記録であった。このとき，T-P のピー クは 7 月 16 日に出現し, 降雨前後の水質の濃度比は 23.0 にも達し，それ以降导大きな変動を示した。これは，7 月 10 日の大雨により，高濃度のT-Pを含んだ流出水が， 浸透水として一旦台地の碰層内に貯留され，それが遅延 後,碩層内の地下水流動に伴って流出したと考えられる。

この河川水は，碑層底部から地下水に供給されたもの である。このときの T-P 濃度は，台地を構成する䃯層な ど地質構造の影響による「水質の不連続性」がもたらさ

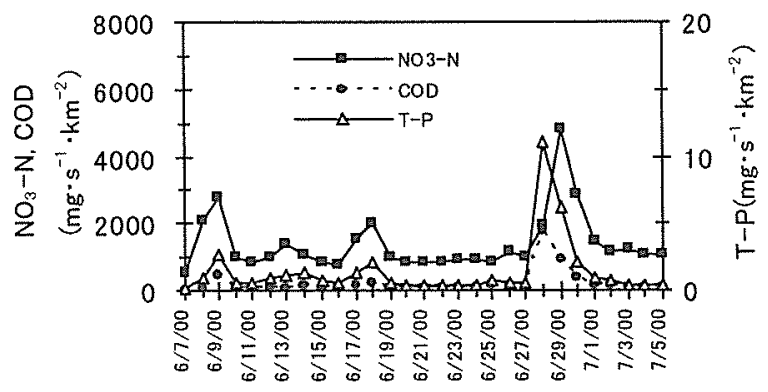

Fig.7 Changes of loads in runoff No.1

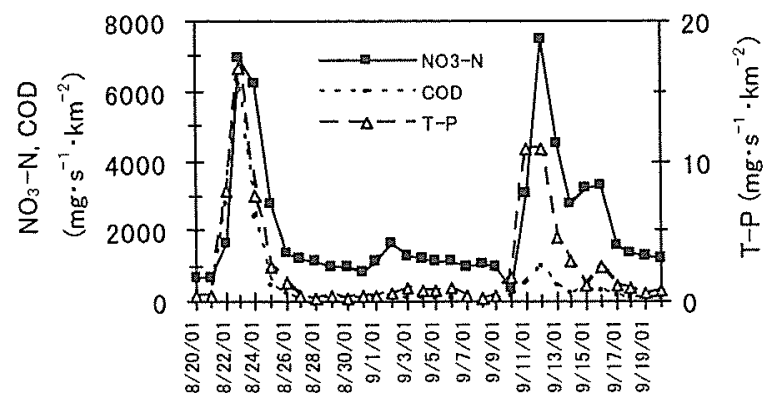

Fig. 8 Changes of loads in runoff No.2,No.3
れていると考えられる ${ }^{31)}$

以上のことから，茶園流域加らの流出水の水質は，水 文気象学的条件の影響を大さく受けるが，茶園における 施肥量や施肥時期などの影響を確認することはできない ことが分かった。

\section{3 降雨時の比負荷の経時変動}

降雨時の比負荷の経時変動を Fig.7〜10に示す。また， 降雨前の比負荷とピーク比負荷を Table 6 に示す。

$\mathrm{NO}_{3}-\mathrm{N}$ 比負荷のピークは，約 $3,600 \sim 7,500 \mathrm{mg} \cdot \mathrm{s}^{-1} \cdot \mathrm{km}^{-2}$ で, 鈴木 ${ }^{11)} ら$ 事例である $200 \mathrm{mg} \cdot \mathrm{s}^{-1} \cdot \mathrm{km}^{-2}$ の 18 ～38 倍 に達する。この差異は，本調查では，茶園流域からの流 出水の $\mathrm{NO}_{3}-\mathrm{N}$ 濃度が非常に高く,さらに総降雨量が多い ため，比流量が大きかったことなどが考えられる。

各降雨時 $\omega \mathrm{NO}_{3}-\mathrm{N}$ 比負荷変動は, 総降雨量が大きいと きに明確なピークを示卞。一方，T-P 比負荷も $\mathrm{NO}_{3}-\mathrm{N}$ と 同様な変動を示すが, No.4 は，ほかのケースと比較して， ピークは小さい值を示す。これは，No.4は,先行晴天日数 が少なく，降雨前の月間降雨日数が 14 日で，さらに月間 総降雨量が $292 \mathrm{~mm}$ と大きいためである。こうした先行 条件の影響を大きく受け， $228 \mathrm{~mm} \cdot \mathrm{d}^{-1}$ と最大の日降雨量 であったが，T-P 比負荷のピークとしては最も低い值を 示した。さらに7月 10 日の日降雨量 $228 \mathrm{~mm} \cdot \mathrm{d}^{-1}$ による 比負荷より，7月 16 日の日降雨量 $35 \mathrm{~mm} \cdot \mathrm{d}^{-1}$ による比負 荷のほうが大きな值を示し，その後も変動を示した。

また，No.5は，8月11日の総降雨量が $195 \mathrm{~mm}$ で，8 月 15 日前後の総降雨量は $355 \mathrm{~mm}$ である。T-P 比負荷は

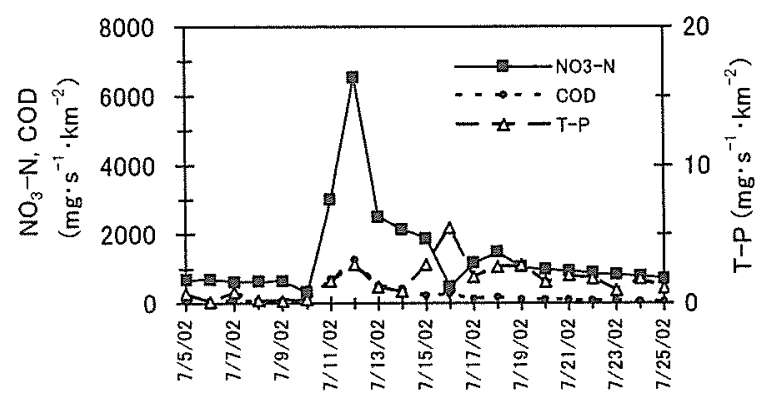

Fig.9 Changes of loads in runoff No.4

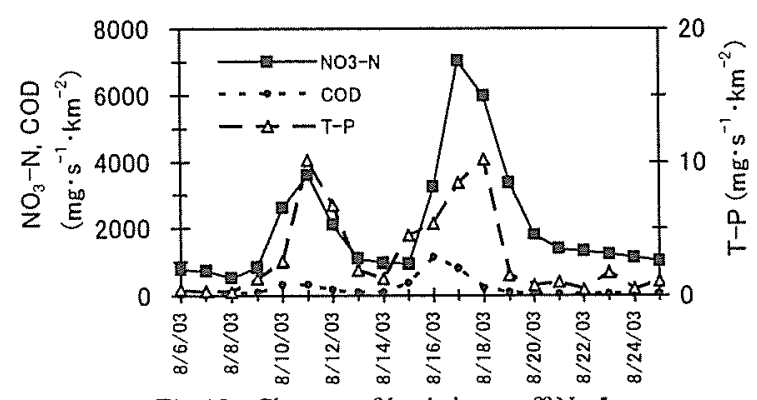

Fig.10 Changes of loads in runoff No.5

Table 6 Maximum specific load of $\mathrm{NO}_{3}-\mathrm{N}, \mathrm{T}-\mathrm{P}$ and $\mathrm{COD}$ in each runoff

\begin{tabular}{|c|c|c|c|c|c|c|c|c|c|}
\hline & \multicolumn{3}{|c|}{$\mathrm{NO}_{3}-\mathrm{N}$} & \multicolumn{3}{|c|}{ T-P } & \multicolumn{3}{|c|}{$\mathrm{COD}$} \\
\hline $\begin{array}{c}\text { Runoff } \\
\text { No. }\end{array}$ & $\begin{array}{c}\text { Before } \\
\text { rain } \\
\left(\mathrm{mg} \cdot \mathrm{s}^{-1} \cdot \mathrm{km}^{-2}\right)\end{array}$ & $\begin{array}{l}\text { Maximum } \\
\left(\mathrm{mg} \cdot \mathrm{s}^{-1} \cdot \mathrm{km}^{-2}\right)\end{array}$ & Ratio & $\begin{array}{c}\text { Before } \\
\text { rain } \\
\left(\mathrm{mg} \cdot \mathrm{s}^{-1} \cdot \mathrm{km}^{-2}\right)\end{array}$ & $\underset{\left(\mathrm{mg} \cdot \mathrm{s}^{-1} \cdot \mathrm{km}^{-2}\right)}{\text { Maximum }}$ & Ratio & $\begin{array}{c}\text { Before } \\
\text { rain } \\
\left(\mathrm{mg} \cdot \mathrm{s}^{-1} \cdot \mathrm{km}^{-2}\right)\end{array}$ & $\underset{\left(\mathrm{mg} \cdot \mathrm{s}^{-1} \cdot \mathrm{km}^{-2}\right)}{\operatorname{Maximum}}$ & Ratio \\
\hline No.1 & 829.0 & 4848.1 & 5.8 & 0.600 & 6.228 & 10.4 & 79.1 & 1753.7 & 22.2 \\
\hline No.2 & 664.6 & 6984.1 & 10.5 & 0.331 & 7.888 & 23.8 & 21.9 & 6196.4 & 282.9 \\
\hline No. 3 & 251.0 & 7502.0 & 29.9 & 0.179 & 10.890 & 60.8 & 58.8 & 974.4 & 16. 8 \\
\hline No.4 & 690.2 & 6541.9 & 9.5 & 0.114 & 2. 842 & 24.9 & 54.4 & 1249.2 & 23. 0 \\
\hline No.5 & 737.5 & 3611.3 & 4.9 & 0.312 & 10.100 & 32.4 & 24.7 & 1108.2 & 44. 9 \\
\hline Average & 634.5 & 5897.5 & 9.3 & 0.307 & 7.590 & 24.7 & 47.6 & 2251.0 & 47.3 \\
\hline
\end{tabular}


$10 \mathrm{mg} \cdot \mathrm{s}^{-1} \cdot \mathrm{km}^{-2}$ 程度で，ほぼ等值であった。これは，前述 の地質構造による地下水帯内での「水質の不連続性」に 起因すると考えられる ${ }^{31)}$ 。

\section{4 降雨時の比流量と比負荷の関係}

降雨 No.1 No.5 について, 降雨前书よび降雨後におけ る比流量を Table 7 に示す。また，Fig.11〜15 に比流量と 比負荷の関係示守。

Fig.11をみると， $\mathrm{NO}_{3}-\mathrm{N}, \mathrm{T}-\mathrm{P}, \mathrm{COD}$ ともに明確なとス 起テリシスが存在する。Fig.12，Fig.13 も同様な変動を 示した。この中で $\mathrm{NO}_{3}-\mathrm{N}$ は, 反時計回りのヒステリシス を示すが，T-P，COD はともに時計回りのヒステリシス を示した。これは， $\mathrm{NO}_{3}-\mathrm{N}$ が溶存態であることから，多 量の降雨によって希釈されて䠆度は低下し，流出水量は 急激に増大し，比負荷はピークを示したと考えられる。

流出水量の低減時は，增水時より比負荷は大きくなっ た。これ忙茶園土壤では，降雨により土溒水分が増加す るため，施肥窒素が土㙋溶液中に多量に溶存し，流出す る。これが降雨後, 表面流出水の急減により希釈効果は 低下し,こ玌により流出水の $\mathrm{NO}_{3}-\mathrm{N}$ 喪度は比較的急に上 昇したためと考えられる。

一方，T-P，COD は水中で䐬濁態を示すものが多いた め，多量の降雨に見舞われると，その時の掃流作用によ

Table 7 Maximum Specific discharge

\begin{tabular}{|c|c|c|c|}
\hline $\begin{array}{c}\text { Rainfall } \\
\text { No. }\end{array}$ & $\begin{array}{c}\text { Before } \\
\text { rain }\end{array}$ & Maximum & Ratio \\
\hline No.1 & 0.023 & 0.346 & 15.0 \\
\hline No.2 & 0.021 & 0.426 & 20.3 \\
\hline No. 3 & 0.044 & 0.435 & 9.9 \\
\hline No.4 & 0.035 & 0.406 & 11.6 \\
\hline No.5 & 0.028 & 0.401 & 14.3 \\
\hline Average & 0.030 & 0.403 & 13.4 \\
\hline
\end{tabular}

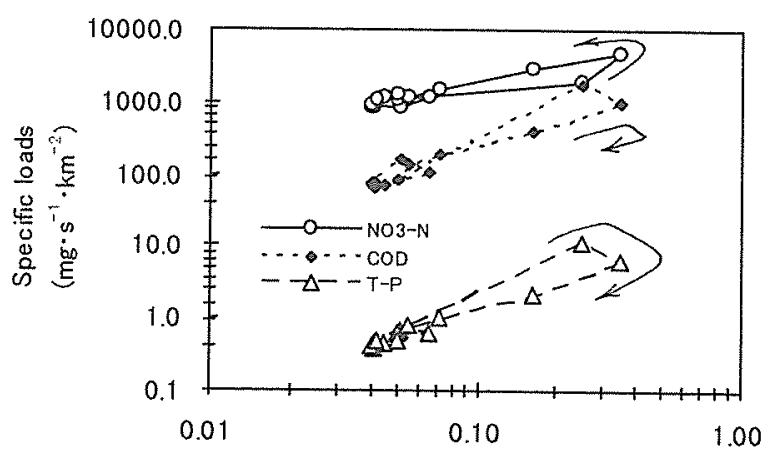

Specific discharge $\left(\mathrm{m}^{3} \cdot \mathrm{s}^{-1} \cdot \mathrm{km}^{-2}\right)$

Fig.11 Hysteresis of loads in run off No.1

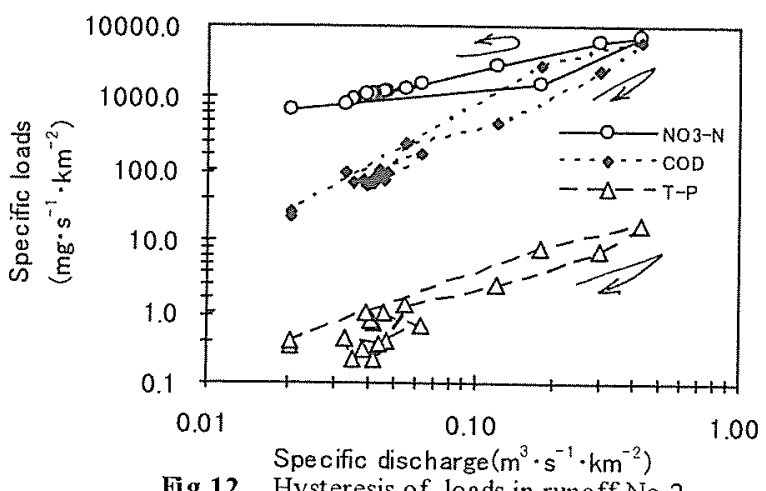

Fig.12 Hysteresis of loads in runoff No.2
り流出水の水質濃度は一挙に増大し，このために比負荷 は急激に大きくなった。その後, 流出水量上流出漲度が ともに急激に低下するため，増水時よりも低減時のほう が低い比負荷でヒステリシスを示すと考えられる。

7月 10 日（Fig. 14)に $228 \mathrm{~mm} \cdot \mathrm{d}^{-1}$ の降水量に見舞われ， 一挙に比負荷は增大した。その後, 次第に流出量が低減 したが，その過程で再び降雨に見舞われたため，比負荷 が一時的に增加したものである。このため, $\mathrm{NO}_{3}-\mathrm{N} の ヒ$ ステリシスは反時計回り，CODは増水時と減水時で，ほ ぼ可逆的な経路を戻り，その間の降雨流出により一時的 に増大を示寸が，時計回りで，ほぼ平常時の比負荷に回 復した。

一方, T-P の変動は, その流出量が低減する過程で, T-P 濃度のピークが出現したため, 平常時の流出水量に 低減しても5 倍程度の比負荷を示した。これは, 流出水 量よりも降雨による流出 T-P 濃度の影響のほうが大きい ためである。

Fig. 15 は，それぞれ二重のルーブ状のヒステリシスを 示している。これは, 1 度目の多量の降雨により, 流出 負荷量は急激に増大し，その後，低減した。そして，乙 の低減する過程で, 再度, 多量の降雨に遭遇したため, 平常時の流出水量に回復する前に，流出負荷量は再び増 大したものである。

このとき, $\mathrm{NO}_{3}-\mathrm{N}$ のステリシスは二重の反時計回り， CODのそれは，二重の時計回りを示した。T-Pは，1度 目の降雨により反時計回りを示し， 2 度目の断続した降 雨で，比負荷は急激に低下した。これは 2 度にわたる断 続した降雨により，濃度が低下したためである。

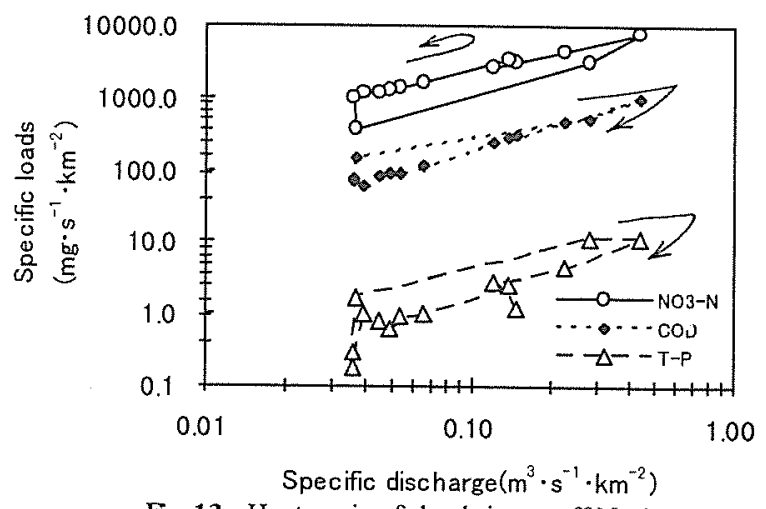

Fig.13 Hysteresis of loads in runoff No.3

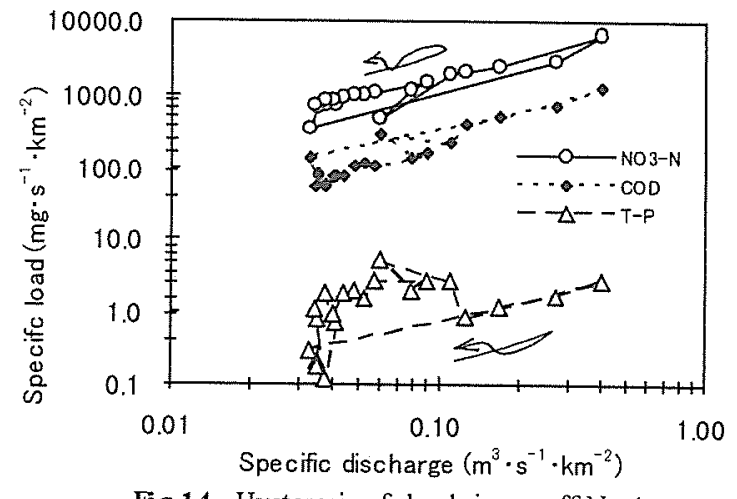

Fig.14 Hysteresis of loads in runoff No.4 


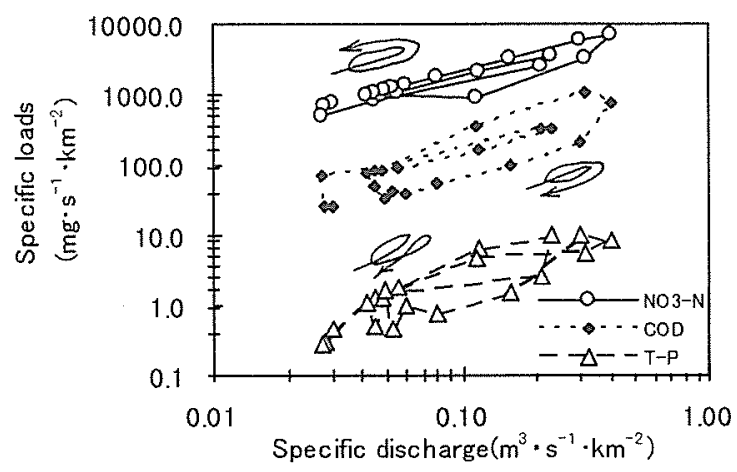

Fig.15 Hysteresis of loads in runoff No.5

\section{5 降雨時の $L-Q$ 式}

調查対象とした降雨 No.1 からNo.5について, 降雨前 からほぼ平常時の流出水量に回復するまでの期間の比流 量と，それに対する比負荷の L-Q を Fig.16 に示す。

降雨 No.1 加ら No.5 をと扰して, $\mathrm{NO}_{3}$-N, T-P 比負荷と 比流量の相関係数は，それぞれ $\mathrm{r}=0.94, \mathrm{r}=0.81$ (各々 $\mathrm{n}=100, \mathrm{P}<0.0001)$ と高く, COD 比負荷のそれは $\mathrm{r}=$ 0.66(n=100，P<0.0001) とやや高かった。それらを比較す ると, $\mathrm{NO}_{3}-\mathrm{N}$ 負荷が最も大きく, $\mathrm{COD}, \mathrm{T}-\mathrm{P}$ の順となっ ている。武田 ${ }^{12}$ らの研究では COD 負荷が最も大きく, $\mathrm{T}-\mathrm{N}, \mathrm{T}-\mathrm{P}$ 負荷の順となっている。この差異は, 本調査 地が $\mathrm{NO}_{3}-\mathrm{N}$ の高排出負荷地域であるためである。一方， 武田 ${ }^{12)} ら か ゙$ 行った水田群での事例のほうが，T-P濃度が 10 倍程度高く, T-P 負荷も大きかった。

多雨期に括訬る総降雨量は，年間降雨量の約 50\%を占 めている。このため, 梅雨期や台風期に生起した大雨, 強雨に伴う $\mathrm{NO}_{3}-\mathrm{N}$ 流出負荷恃，そのときの流出水量に 大きく影響され，総流出負荷量は非常に大きく、「水質災 害」ともいえる現象が生起していると考えられる。

\section{6. まと め}

本研究では, 静岡県牧ノ原台地における集団茶園流域 を調査地とし，特に大きな降雨流出時の河川水質と流出 負荷特性について検討を行った。その結果を要約すると， 次のようである。

1）降雨前の $\mathrm{NO}_{3}-\mathrm{N}$ 濃度は, 月間の先行降雨量, 先行 降雨日数に大きく影響された。 $\mathrm{NO}_{3}-\mathrm{N}$ の降雨前後の水質 濃度 (降雨前/降雨後) 比の平均は 2.8, T-P, COD の降 雨前後の㜊度 (降雨後/降雨前) 比の平均俚それぞれ 6.2, 4.9 で，最大は T-Pの 23.0 であった。

2）降雨時の $\mathrm{NO}_{3}-\mathrm{N}$ 濃度は，大きな降雨のとき，先行 条件の影響を大きく受けて，1/3 程度に低下した。T-P， $\mathrm{COD}$ は 2 10 倍程度に上昇した。 $\mathrm{NO}_{3}-\mathrm{N}$ 浱度の回復速 度は，降雨後 $1 \sim 2$ 日間で最も大きく，平均 $3 \mathrm{mg} \cdot l^{-1} \cdot \mathrm{d}^{-1}$ であった。

3）比流量と比負荷の関係では， $\mathrm{NO}_{3}-\mathrm{N}$ は反時計回り のヒステリシスを示し，T-P, COD は時計回りのヒステ リシスを示した。短期間に再度，大雨に見舞われると， それぞれ二重のヒステレシスを示した。

4) 降雨時の $\mathrm{L}-\mathrm{Q}$ 式では, $\mathrm{NO}_{3}-\mathrm{N}, \mathrm{T}-\mathrm{P}$ 住相関が高 $<(\mathrm{r}=$ $0.94, r=0.81), C O D$ はやや高い相関 $(r=0.66)$ を示した。 $\mathrm{NO}_{3} \cdot \mathrm{N}$ 負荷は流出水量の影響を最も受けやすく，次に

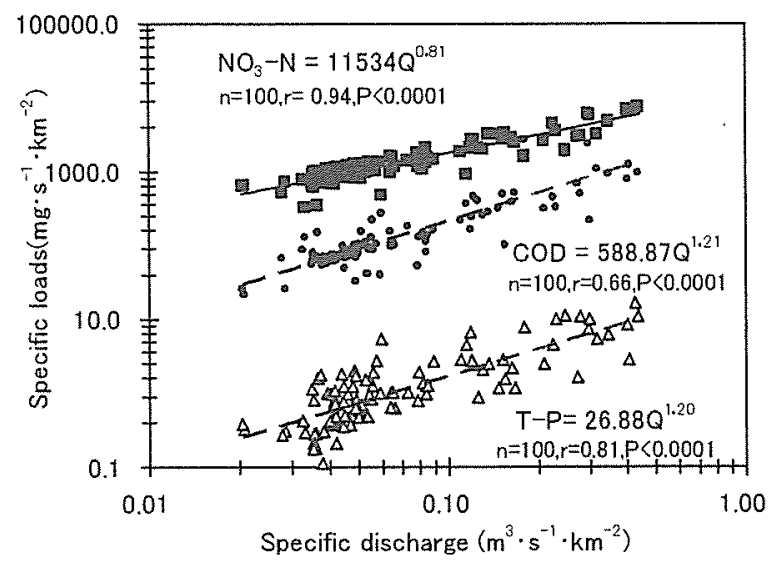

Fig.16 The relations between discharge and loads

COD, T-P の順であった。

5）降雨前の比負荷に対し, 降雨時のピーク負荷は最大 で, $\mathrm{NO}_{3}-\mathrm{N}$ が約 30 倍, T-P は約 60 倍, $\mathrm{COD}$ は約 280 倍にも達した。

謝 辞

本研究は，文部科学省科学研究費（基盤 $A, 14206027$, 代表者 茨城大学農学部 中曾根英雄教授）の助成を受 けて行われた。現地測定に際し，静岡県菊川市の関係各 課のご支援を頂いた。ここに記して，感謝の意を表する。 （原稿受付 2005 年10月 19 日) (原稿受理 2006年5月 26日)

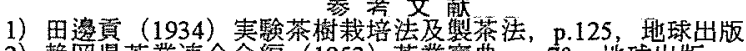

2) 静岡導茶莱連合会蹁 (1953) 茶菜珼典, p.70, 地球出版。

3) 上林熊次郎, 江口高硶編述 (1877) 恭莱必要下, p.19, 和泉屋

4) 大石貝男 $(1981)$ 一明治維新之茶菜一较之原開拓史考, pp.116-117,

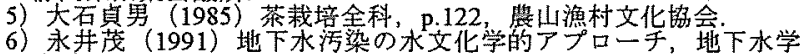
会誌, 33, 145-154.

7) 素誌, 33, $145-154$

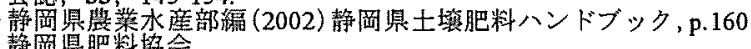
静岡県肥料劦会

8) 中鱼根英雄，中村良太 (1984)降雨時における烏川の水質変動

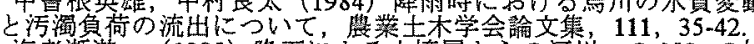

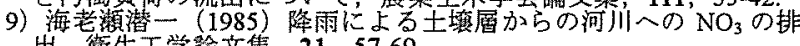
出，衙生工学辆齐集，21，57-69.

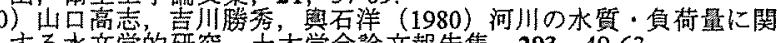

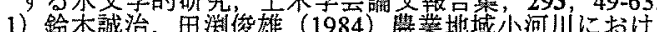

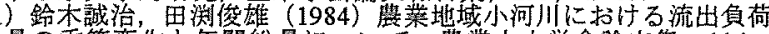
量の季節変化と年間総量について，鹿学士木学会論文集，114， 33-38.

12）武田郁郎，國松孝男，小林㭡太郎，丸山利韩 (1990)降雨時に

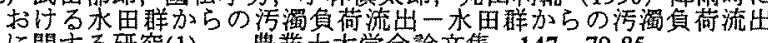

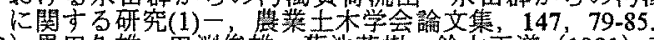

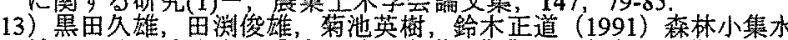
域に扔ける流出水の激度と流出負荷，啀業土木学会諭文集，154， 25-35.

14）志村をと子，田㴊俊雄（2003）羲豚地城における降雨增水時の

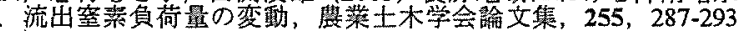

15) Grosz. J.R. (1978) Nitrogen Input to Stream Water from Forests along an Elevational Gradient in New Mexico, Water Research, 12, 725-734. 16) Jacobs. T.C. and Gillian. J.W. (1985) Riparian Losses of Nitrate

from Agricultural Drainage water, $\bar{J}$, Environ Qual, 14(4) 472-478.

18) 日本彥象学会編 (1998) 気像科学事典, p.291, p.62, 東京書籍

19) 土隆一 (2001), 静岡県の地形々地䲞, p.66, 呙外地图。

20) 河合物吾 (1965) 本邦に打引る茶園土境に関する研究，莀林省 茶莱呀䮖場研究報告， 2, 1-235.

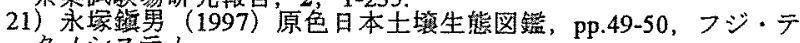

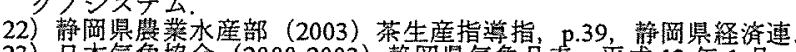
23) 日本気像萔会 $(2000-2003)$ 静岡県気象月表, 平成 13 年 1 月

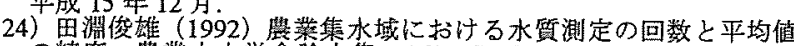
の精度, 娄掌士李学会論文集, 160, 71-72.

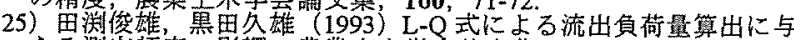

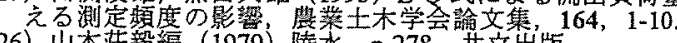

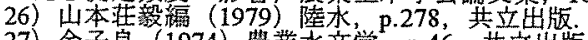

27) 金子良 (1974) 展落水文学, p.46，共立出版。

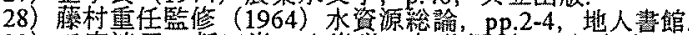

29) 宫洸三, 新田尚, 山岸栄二郎共斒 (1997) 気像の百科事典,

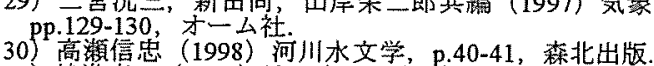

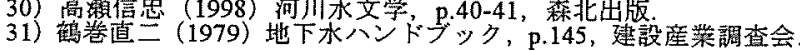

